\title{
Three-dimensional hybrid networks based on aspartic acid
}

\author{
ANUPAMA GHOSH ${ }^{1,2, *}$ and R A SANGURAMATH ${ }^{2}$ \\ ${ }^{1}$ Solid State and Structural Chemistry Unit, Indian Institute of Science, Bangalore 560012 \\ ${ }^{2}$ Chemistry and Physics of Materials Unit and CSIR Centre of Excellence in Chemistry, \\ Jawaharlal Nehru Centre for Advanced Scientific Research, Bangalore 560064 \\ e-mail: anupamag $a$ jncasr.ac.in
}

\begin{abstract}
Three-dimensional achiral coordination polymers of the general formula $\mathrm{M}_{2}(\mathrm{D}, \mathrm{L}-\mathrm{NHCH}$ $\left.(\mathrm{COO}) \mathrm{CH}_{2} \mathrm{COO}\right)_{2} \cdot \mathrm{C}_{4} \mathrm{H}_{4} \mathrm{~N}_{2}$ where $\mathrm{M}=\mathrm{Ni}$ and $\mathrm{Co}$ and pyrazine acts as the linker molecule have been prepared under hydrothermal conditions starting with $\left[\mathrm{M}\left(\mathrm{L}-\mathrm{NHCH}(\mathrm{COO}) \mathrm{CH}_{2} \mathrm{COO}\right) \cdot 3 \mathrm{H}_{2} \mathrm{O}\right]$ possessing a helical chain structure. A three-dimensional hybrid compound of the formula $\mathrm{Pb}_{2.5}[\mathrm{~N}\{\mathrm{CH}(\mathrm{COO})$ $\left.\left.\mathrm{CH}_{2} \mathrm{COO}\right\}_{2} 2 \mathrm{H}_{2} \mathrm{O}\right]$ has also been prepared hydrothermally starting with aspartic acid and $\mathrm{Pb}\left(\mathrm{NO}_{3}\right)_{2}$. In this lead compound, where a secondary amine formed by the dimerisation of aspartic acid acts as the ligand, there is two-dimensional inorganic connectivity and one-dimensional organic connectivity.
\end{abstract}

Keywords. Aspartic acid; hybrid compounds; nickel aspartate; lead aspartate; achiral frameworks.

\section{Introduction}

Open-framework hybrid networks involving metal silicates, phosphates and sulphates have been areas of great interest in the past few decades. ${ }^{1-3}$ Much attention is being paid in the last few years to organicinorganic hybrid frameworks formed by metal carboxylates and phosphonates ${ }^{4-7}$ because of their structural diversity and possible applications in catalysis ${ }^{8,9}$, separation $^{10,11}$ and hydrogen storage. ${ }^{12,13}$ Natural amino acids have been used extensively to form coordination polymers with transition metals since both the carboxylate and the amino groups can coordinate to the metal depending upon the $\mathrm{pH}$ of the medium. ${ }^{14-16}$ Aspartic acid, $\mathrm{NH}_{2} \mathrm{CH}(\mathrm{COOH}) \mathrm{CH}_{2} \mathrm{COOH}$, is an acidic amino acid with one amino and two carboxylic acid groups. As these functional groups are capable of binding to the metal centres in different coordination modes it is exploited greatly to form hybrid metal-organic framework structures. Chiral and achiral metal aspartates with extended structures have been reported in the recent literature. ${ }^{17-19}$ In the present work, we report two metal-organic framework structures derived from aspartic acid. We report a three-dimensional racemic structure of the formula $\mathrm{Ni}_{2}\left(\mathrm{D}, \mathrm{L}-\mathrm{NHCH}(\mathrm{COO}) \mathrm{CH}_{2} \mathrm{COO}\right)_{2} . \mathrm{C}_{4} \mathrm{H}_{4} \mathrm{~N}_{2}$, $\mathrm{I}$, by connecting helical nickel aspartate chains with

\footnotetext{
*For correspondence
}

the bi-dentate aromatic linker pyrazine. We have obtained an analogous cobalt compound of the formula $\mathrm{Co}_{2}$ (D, L-NHCH(COO) $\left.\mathrm{CH}_{2} \mathrm{COO}\right)_{2} . \mathrm{C}_{4} \mathrm{H}_{4} \mathrm{~N}_{2}$, II, starting with cobalt aspartate. We also report a threedimensional hybrid lead compound of the formula $\mathrm{Pb}_{2.5}\left[\mathrm{~N}\left\{\mathrm{CH}(\mathrm{COO}) \mathrm{CH}_{2} \mathrm{COO}\right\}_{2} \cdot 2 \mathrm{H}_{2} \mathrm{O}\right]$, III, resulting from the hydrothermal reaction between $\mathrm{Pb}\left(\mathrm{NO}_{3}\right)_{2}$ and aspartic acid, where the ligand is a secondary amine formed by the dimerisation of aspartic acid. In III, there is two-dimensional inorganic connectivity and one-dimensional organic connectivity.

\section{Experimental}

\subsection{Synthesis and initial characterization}

In order to prepare $\mathrm{Ni}_{2}\left(\mathrm{D}, \mathrm{L}-\mathrm{NHCH}(\mathrm{COO}) \mathrm{CH}_{2} \mathrm{COO}\right)_{2}$. $\mathrm{C}_{4} \mathrm{H}_{4} \mathrm{~N}_{2}, \quad$ I, $54.9 \mathrm{mg}$ of Ni-asp [ $\mathrm{Ni}(\mathrm{L}-\mathrm{NHCH}(\mathrm{COO})$ $\left.\mathrm{CH}_{2} \mathrm{COO}\right) \cdot 3 \mathrm{H}_{2} \mathrm{O}$ ] were dissolved in water $(3 \mathrm{~mL})$ ethanol $(2 \mathrm{~mL})$ mixture to which pyrazine $(16.90 \mathrm{mg})$ was added. The resultant solution with Ni-asp : pyrazine ratio of $1: 1$ was stirred for $1 \mathrm{~h}$ and transferred to a $23 \mathrm{~mL}$ PTFE-lined acid digestion bomb and heated at $150^{\circ} \mathrm{C}$ for $48 \mathrm{~h}$. The $\mathrm{pH}$ of the solution was kept at around 5-6. Shiny bluish green coloured crystals so obtained were vacuum filtered and washed with water.

The cobalt analogue of $\mathbf{I}$, was prepared as follows. $131.0 \mathrm{mg}$ of Co-asp [Co(L-NHCH$\left.(\mathrm{COO}) \mathrm{CH}_{2} \mathrm{COO}\right)$. 
$\left.3 \mathrm{H}_{2} \mathrm{O}\right]$ were dissolved in water $(5 \mathrm{~mL})$-ethanol $(5 \mathrm{~mL})$ mixture to which pyrazine $(80.80 \mathrm{mg})$ was added. The resultant solution with Co-asp : pyrazine ratio of $1: 2$ was stirred for $1 \mathrm{~h}$ and transferred to a $23 \mathrm{~mL}$ PTFE-lined acid digestion bomb and heated at $150^{\circ} \mathrm{C}$ for $48 \mathrm{~h}$. The $\mathrm{pH}$ of the solution was kept at around 5-6. Dark red coloured solid so obtained were vacuum filtered and washed with water.

$\mathrm{Pb}_{2.5}\left[\mathrm{~N}\left\{\mathrm{CH}(\mathrm{COO}) \mathrm{CH}_{2} \mathrm{COO}\right\}_{2} 2 \mathrm{H}_{2} \mathrm{O}\right]$, III, was prepared as follows. $334.5 \mathrm{mg}$ of $\mathrm{Pb}\left(\mathrm{NO}_{3}\right)_{2}$ were dissolved in water $(5 \mathrm{~mL})$ to which L-aspartic acid (203.70 mg) was added. To the resultant mixture, with a $\mathrm{Pb}\left(\mathrm{NO}_{3}\right)_{2}$ :aspartic acid ratio of $1: 1 \cdot 5,1$ molar $\mathrm{NaOH}$ solution was added drop-wise to make the $\mathrm{pH}$ of the solution equal to 5 . The solution was stirred for an hour and transferred to a $23 \mathrm{~mL}$ PTFE-lined acid digestion bomb and heated at $150^{\circ} \mathrm{C}$ for $72 \mathrm{~h}$. Beautiful colorless crystals so obtained were vacuum filtered and washed with water.

The precursor materials $\mathrm{Ni}$-asp and Co-asp were prepared as follows. A 1:1 mixture of $\mathrm{Ni}(\mathrm{Co}) \mathrm{Cl}_{2}$. $6 \mathrm{H}_{2} \mathrm{O}$ : aspartic acid was taken in a vial and dissolved in water. Triethylamine was added to maintain the $\mathrm{pH}$ at around 5. The resultant mixture was kept on a hot water bath for slow evaporation. After 3 days green crystals of the composition $[\mathrm{Ni}(\mathrm{L}-$ $\left.\mathrm{NHCH}(\mathrm{COO}) \mathrm{CH}_{2} \mathrm{COO}\right) \cdot 3 \mathrm{H}_{2} \mathrm{O}$ l and pink coloured crystals of $\left[\mathrm{Co}\left(\mathrm{L}-\mathrm{NHCH}(\mathrm{COO}) \mathrm{CH}_{2} \mathrm{COO}\right) \cdot 3 \mathrm{H}_{2} \mathrm{O}\right]$ were obtained. The crystals were vacuum filtered and washed with water. These precursors are similar in structure. ${ }^{14}$

Initial characterization of the compounds I, II and III were carried out by powder X-ray diffraction (PXRD), thermogravimetric analysis (TGA), and IR spectroscopy. PXRD patterns indicated the products to be new materials and monophasic, the patterns being consistent with those generated from singlecrystal X-ray diffraction. Elemental analysis of I, II and III were satisfactory. Elemental analysis for $\mathbf{I}$ : C, $31.7 \%$; H, $2.7 \%$ N, $12.3 \%$. Observed: C, $31.8 \%$; $\mathrm{H}, 3.7 \% \mathrm{~N}, 12.1 \%$; for II: C, $31.7 \% ; \mathrm{H}, 2.7 \% \mathrm{~N}$, $12.3 \%$. Observed: C, $31.9 \%$; $, 3.1 \% \mathrm{~N}, 12.0 \%$; for III: Calculated: $\mathrm{C}, 12.5 \% ; \mathrm{H}, 1.3 \% \mathrm{~N}, 1.8 \%$. Observed: C, $13.0 \% ; \mathrm{H}, 1.2 \% \mathrm{~N}, 1.9 \%$; Infrared spectra of I, II and III show characteristic bands in the region $1400-1600 \mathrm{~cm}^{-1}$ and $3300-3400 \mathrm{~cm}^{-1}$ due to carboxylate and amine group stretching vibration of the aspartate moiety. Beside that, bands due to $\mathrm{C}-\mathrm{H}$ and $\mathrm{C}-\mathrm{C}$ stretching and bending vibrations have also been characterized ${ }^{20} \mathrm{~A}$ broad band in the 2800$3200 \mathrm{~cm}^{-1}$ region in the spectra of those compounds indicates the presence of extensive hydrogen bonding.

Thermogravimetric analysis of above compounds was carried out under constant flow of $\mathrm{O}_{2}$ at a heating rate of $5^{\circ} \mathrm{C} \mathrm{min}^{-1}$ in the temperature range $30-900^{\circ} \mathrm{C}$. Compound I showed a two-step weight loss corresponding to the loss of aspartic acid and pyrazine molecules in the range $350-450^{\circ} \mathrm{C}$ and $450-550^{\circ} \mathrm{C}$ (obs $=74 \cdot 1 \%$, calcd $=74.8 \%$ ). Compound II showed the same type of TGA curve. Compound III showed a two-step weight loss corresponding to the loss of water molecules and aspartic acid dimer molecule in the range $200-450^{\circ} \mathrm{C}$ and $450-550^{\circ} \mathrm{C}$ (obs $=33 \cdot 3 \%$, calcd $=35 \cdot 1 \%$ ).

\subsection{Single crystal structure determination}

Suitable single crystals of I and III were carefully selected under a polarizing microscope and glued at the tip of a thin glass fibre with cyano-acrylate (superglue) adhesive. Single crystal structure determination by X-ray diffraction was performed on a Bruker Smart-CCD diffractometer equipped with a normal focus, $2.4 \mathrm{~kW}$ sealed tube X-ray source (Mo-K $\mathrm{K}_{\alpha}$ radiation, $\lambda=0.71073 \AA$ ) operating at $50 \mathrm{kV}$ and $35 \mathrm{~mA}$. A hemisphere of intensity data was collected at room temperature with $\omega$ space scans (width of $0.30^{\circ}$ and exposure time of 10 or $20 \mathrm{~s}$ per frame). Pertinent experimental details of the structure determination for compounds I and III and are presented in table 1 .

The structures were solved by direct methods using SHELXS-86, ${ }^{21}$ which readily established the heavy atom position $(\mathrm{Pb}$ and $\mathrm{Ni})$ and facilitated the identification of the light atoms $(\mathrm{O}, \mathrm{N}, \mathrm{C}, \mathrm{H})$ from difference Fourier maps. An empirical absorption correction based on symmetry equivalent reflections was applied using the SADABS programme. ${ }^{22}$ All the hydrogen positions were initially located in the difference Fourier maps and the hydrogen atoms were placed geometrically and held in the riding mode for the final refinement. With the single crystal X-ray data collected at room temperature, few of the hydrogen atoms of the water molecules of III could not be located from the difference Fourier maps. The last cycle of refinement included atomic positions for all the atoms, anisotropic thermal parameters for all the non-hydrogen atoms and isotropic thermal parameters for all the hydrogen atoms. Full-matrix-least-squares structure refinement against 
Table 1. Crystal data and structure refinement parameters for compound I and $\mathbf{I I I}^{\mathrm{a}}$.

\begin{tabular}{|c|c|c|}
\hline Parameters & $\mathbf{I}^{\mathrm{b}}$ & III \\
\hline Empirical formula & $\mathrm{Ni}_{2} \mathrm{~N}_{4} \mathrm{C}_{12} \mathrm{H}_{12} \mathrm{O}_{8}$ & $\mathrm{~Pb}_{2.5} \mathrm{NC}_{8} \mathrm{O}_{10} \mathrm{H}_{10}$ \\
\hline Crystal system & Orthorhombic & Monoclinic \\
\hline Space group & Pnn2 & $P 2(1)$ \\
\hline Crystal size (mm) & $0.28 \times 0.38 \times 0.18$ & $0.28 \times 0.18 \times 0.16$ \\
\hline$a(\AA)$ & $15 \cdot 4137(6)$ & $9.6521(6)$ \\
\hline$b(\AA)$ & $6 \cdot 5818(2)$ & $9 \cdot 7770(6)$ \\
\hline$c(\AA)$ & $7 \cdot 8808(3)$ & $10 \cdot 0407(6)$ \\
\hline$\alpha\left(^{\circ}\right)$ & $90 \cdot 0$ & $89.9270(10)$ \\
\hline$\beta\left(^{\circ}\right)$ & $90 \cdot 0$ & $70 \cdot 0980(10)$ \\
\hline$\gamma\left({ }^{\circ}\right)$ & $90 \cdot 0$ & $62 \cdot 9510(10)$ \\
\hline Volume $\left(\AA^{3}\right)$ & $799 \cdot 51(5)$ & $780 \cdot 04(8)$ \\
\hline$Z$ & 4 & 5 \\
\hline Formula mass & $203 \cdot 48$ & $250 \cdot 22$ \\
\hline$\rho_{\text {calc }}\left(\mathrm{g} \mathrm{cm}^{-3}\right)$ & $2 \cdot 113$ & $4 \cdot 794$ \\
\hline$\lambda(\mathrm{MoK} \alpha) \AA$ & 0.71073 & 0.71073 \\
\hline$M\left(\mathrm{~mm}^{-1}\right)$ & 5.796 & $48 \cdot 418$ \\
\hline$\theta$ range $\left(^{\circ}\right)$ & 2.64 to 27.89 & 0.999 to 25.59 \\
\hline Total data collected & 4266 & 10664 \\
\hline Limiting indices & $-20 \leq h \leq 11,-5 \leq k \leq 8,-9 \leq 1 \leq 10$ & $-11 \leq h \leq 11,-11 \leq k \leq 11,-12 \leq 1 \leq 12$ \\
\hline Unique data & 1754 & 2926 \\
\hline Observed data $(I>2 \sigma(I))$ & 1266 & 2542 \\
\hline Refinement method & Full-matrix least squares on $\left|F^{2}\right|$ & Full-matrix least squares on $\left|F^{2}\right|$ \\
\hline$R_{\text {int }}$ & 0.0300 & 0.0382 \\
\hline$R$ indexes $[I>2 \sigma(I)]$ & $R_{1}=0.0465, w R_{2}=0.1186$ & $R_{1}=0.0521, w R_{2}=0.1391$ \\
\hline$R$ (all data) & $R_{1}=0.0801, w R_{2}=0.1534$ & $R_{1}=0.0629, w R_{2}=0.1575$ \\
\hline Goodness of fit & 1.082 & $1 \cdot 186$ \\
\hline No. of variables & 118 & 197 \\
\hline $\begin{array}{l}\text { Largest difference map } \\
\text { peak and hole e. } \AA^{-3}\end{array}$ & 0.712 and -0.749 & $5 \cdot 817$ and -1.998 \\
\hline
\end{tabular}

${ }^{\mathrm{a}} R_{1}=\sum|| F_{\mathrm{o}}|-| F_{\mathrm{c}}|| / \Sigma\left|F_{\mathrm{o}}\right| ; \quad{ }^{\mathrm{b}} w R_{2}=\left\{\sum\left[w\left(F_{\mathrm{o}}{ }^{2}-F_{\mathrm{c}}{ }^{2}\right)^{2}\right] / \sum\left[w\left(F_{\mathrm{o}}{ }^{2}\right)^{2}\right]\right\}^{1 / 2}, \quad w=1 /\left[\sigma^{2}\left(F_{\mathrm{o}}\right)^{2}+(a P)^{2}+b P\right], \quad P=\left(F_{\mathrm{o}}{ }^{2}+2 F_{\mathrm{c}}{ }^{2}\right) / 3$, $a=0.0856$ and $b=0.0000$ for $\mathbf{I}$

$a=0.0890$ and $b=7.4879$ for III

${ }^{\mathrm{b}}$ Unit cell dimensions of II, the cobalt analogue of $\mathbf{I}$ are $a(\AA)=16 \cdot 01, b(\AA)=6 \cdot 81, c(\AA)=8 \cdot 34, \alpha\left(^{\circ}\right)=90 \cdot 0, \beta\left({ }^{\circ}\right)=$ $90.0, \gamma\left({ }^{\circ}\right)=90 \cdot 0$, volume $\left(\AA^{3}\right)=909 \cdot 0$

$\left|F^{2}\right|$ was carried out using the SHELXTL-PLUS package of programs. ${ }^{23}$

\section{Results and discussion}

We have prepared an achiral three-dimensional coordination polymer $\mathrm{Ni}_{2}\left(\mathrm{D}, \mathrm{L}-\mathrm{NHCH}(\mathrm{COO}) \mathrm{CH}_{2} \mathrm{COO}\right)_{2}$. $\mathrm{C}_{4} \mathrm{H}_{4} \mathrm{~N}_{2}$, I, by the hydrothermal reaction of nickel aspartate trihydrate salt $\mathrm{Ni}\left(\mathrm{L}-\mathrm{NHCH}(\mathrm{COO}) \mathrm{CH}_{2} \mathrm{COO}\right)$. $3 \mathrm{H}_{2} \mathrm{O}$ possessing a chiral one-dimensional helical extended chain structure with pyrazine. The asymmetric unit of I (figure la) contains 13 non-hydrogen atoms, with one $\mathrm{Ni}$ atom, one aspartate molecule and half of the pyrazine ligand. The coordination number $\mathrm{Ni}$ is six and coordinated to carboxylate oxygen and nitrogen atoms of the aspartic acid as well as nitrogen atom of pyrazine molecule. All the oxygen and nitrogens take part in coordination and aspartic acid act as quinque dentate ligand. At this high temperature L-acid undergoes racemisation and both the L- and D-acid exist in the structure which is reflected on the achiral space group of the crystal. Water molecules of the nickel aspartate trihydrate are replaced by aspartic acid oxygens and pyrazine nitrogens to give a three-dimensional structure. In I, L- and D-nickel aspartate helices are joined together by carboxylate bridges to form the $b c$ plane of the crystals. These layers are joined together by pyrazine linkers in a zigzag fashion along the $a$ direction of the unit cell to give a porous threedimensional network (figure $1 \mathrm{~b}$ ). The polyhedral view of the structure down the $c$ axis of the unit cell shows rectangular pores (figure 1c). The inorganic and organic connectivities in I are zero and three re- 
spectively which can be specified as the $\mathrm{I}^{0} \mathrm{O}^{3}$ type. The $\mathrm{Ni}-\mathrm{O}$ bond length in the nickel aspartate moiety of $\mathbf{I}$ is in the range of $2 \cdot 038(0)-2 \cdot 101(0) \AA$ (average $2.068 \AA$ ) with $\mathrm{Ni}-\mathrm{N}$ bond length being 2.079(0) $\AA$. The average $\mathrm{C}-\mathrm{O}, \mathrm{C}-\mathrm{C}$ and $\mathrm{C}-\mathrm{N}$ distances of the

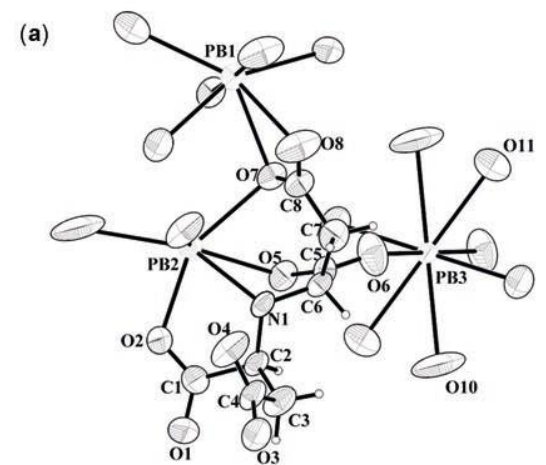

(b)

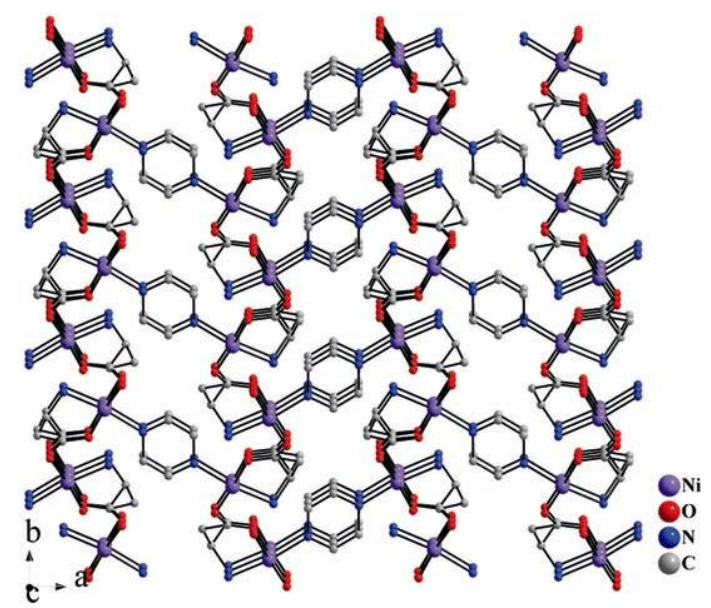

(c)

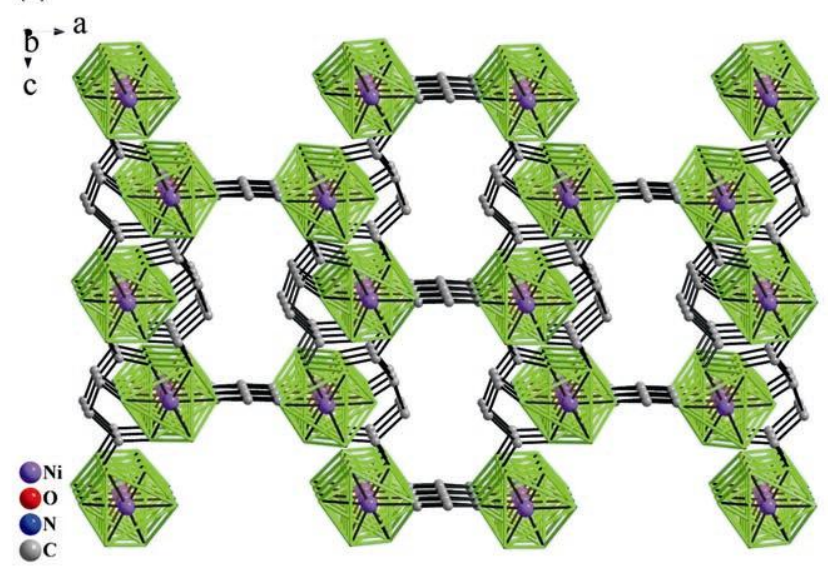

Figure 1. (a) ORTEP plot of $\mathrm{Ni}(\mathrm{D}, \mathrm{L}-\mathrm{NH}-\mathrm{CH}(\mathrm{COO})$ $\mathrm{CH}_{2} \mathrm{COO}$ ). $\mathrm{C}_{2} \mathrm{H}_{2} \mathrm{~N}$, I. Thermal ellipsoids are shown at $50 \%$ probability. Only the asymmetric part is labelled. (b) Three-dimensional structure of $\mathbf{I}$ viewed along the $c$ axis of the unit cell. Hydrogen atoms are not shown for clarity. (c) Polyhedral view of I viewed along the $b$ axis of the unit cell. aspartic acid are $1.258,1.577$ and $1.552 \AA$ respectively. The Ni-N (pyrazine) bond length is $2.098 \AA$ while the average $\mathrm{C}-\mathrm{N}$ distance in the pyrazine ring is $1.329 \AA$.

(a)
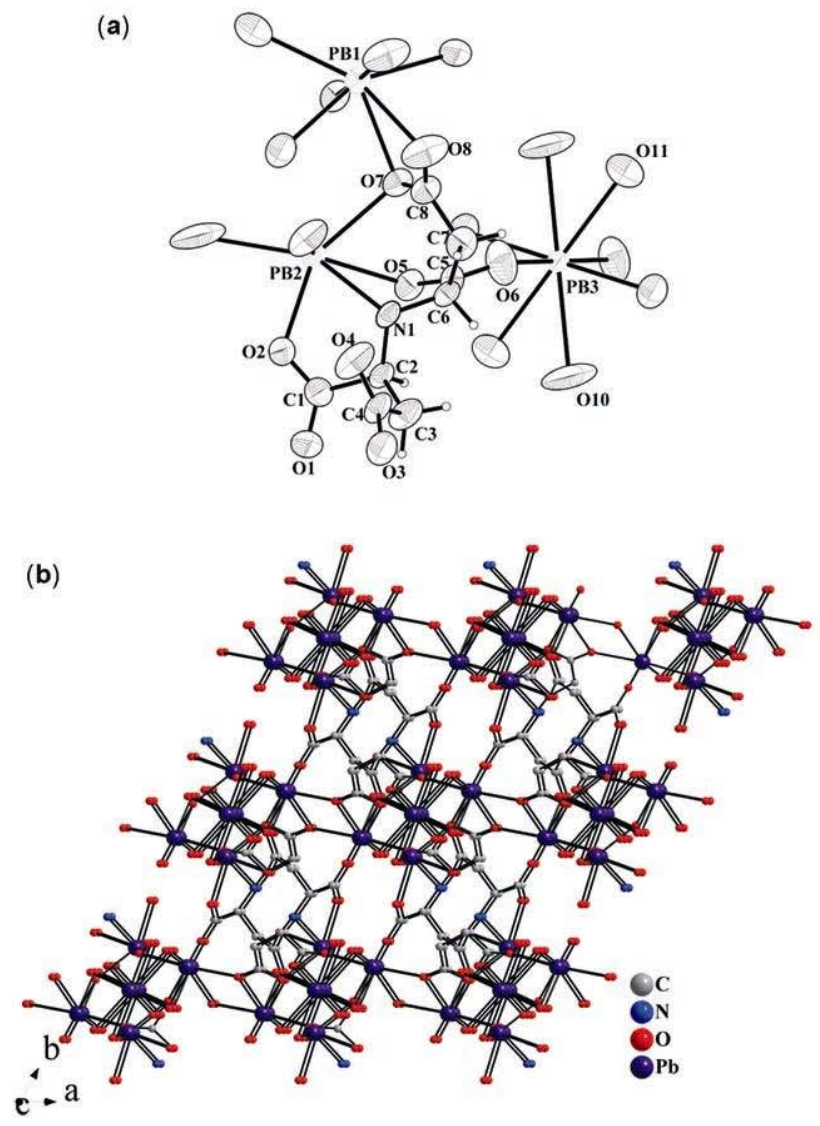

(c)

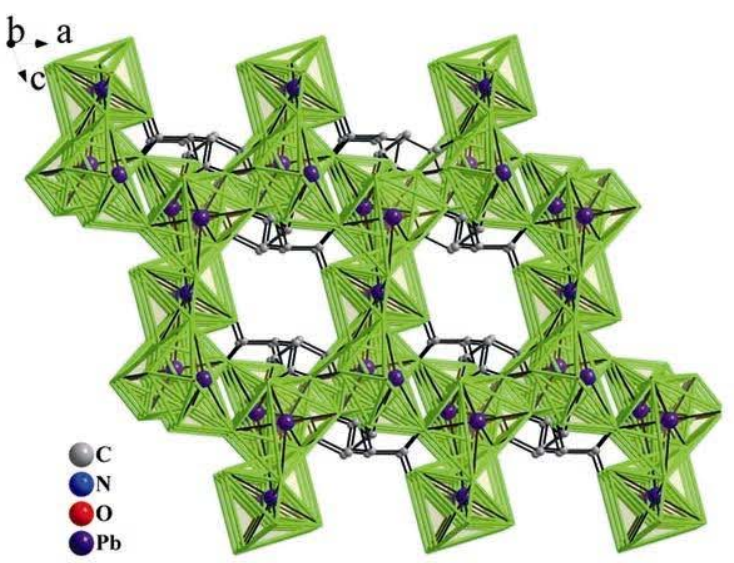

Figure 2. (a) ORTEP plot of $\mathrm{Pb}_{2.5}\left[\mathrm{~N}\left\{\mathrm{CH}(\mathrm{COO}) \mathrm{CH}_{2}\right.\right.$ COO $2 \mathrm{H}_{2} \mathrm{O}$, III. Thermal ellipsoids are shown at $50 \%$ probability. Only the asymmetric part is labelled. (b) Three-dimensional structure of III viewed along the $c$ axis of the unit cell. Hydrogen atoms are not shown for clarity. (c) Polyhedral view of III viewed along the $b$ axis of the unit cell. 
The cobalt analogue $\mathrm{Co}_{2}(\mathrm{D}, \mathrm{L}-\mathrm{NHCH}(\mathrm{COO})$ $\left.\mathrm{CH}_{2} \mathrm{COO}\right)_{2} \cdot \mathrm{C}_{4} \mathrm{H}_{4} \mathrm{~N}_{2}$, II, is isomorphous with $\mathbf{I}$ and gave an identical powdered $\mathrm{X}$-ray diffraction pattern. The unit cell parameters of II are given in table. 1 .

We have obtained an achiral three-dimensional compound of the formula $\mathrm{Pb}_{2.5}[\mathrm{~N}\{\mathrm{CH}(\mathrm{COO})$ $\left.\mathrm{CH}_{2} \mathrm{COO}\right\}_{2} \cdot 2 \mathrm{H}_{2} \mathrm{O}$ ], III, from the high-temperature reaction of $\mathrm{L}$-aspartic acid and $\mathrm{Pb}\left(\mathrm{NO}_{3}\right)_{2}$. This compound results from the dimerisation of aspartic acid to give a secondary amine as per the following reaction:

$$
\begin{aligned}
& {\left[\mathrm{NH}_{2} \mathrm{CH}(\mathrm{COO}) \mathrm{CH}_{2} \mathrm{COO}\right]^{2-}+\mathrm{OH}^{-} \rightarrow} \\
& {\left[\mathrm{NH}\left\{\mathrm{CH}(\mathrm{COO}) \mathrm{CH}_{2} \mathrm{COO}\right\}_{2}\right]^{4-}+\mathrm{H}_{2} \mathrm{O} .}
\end{aligned}
$$

The asymmetric unit of III (figure 2a) contains 20 non-hydrogen atoms, with three crystallographically independent $\mathrm{Pb}$ atoms, two water molecules bridging the lead centers and one aspartic acid dimer molecule. The coordination number of $\mathrm{Pbl}$ is seven and coordinated to water molecules as well as carboxylate oxygens of the ligand moiety while coordination number of $\mathrm{Pb} 2$ is six and is ligated through water molecules as well as the amine nitrogen and caboxylate oxygens of the ligand. Both of the lead atoms have somewhat distorted geometry and shows hemidirectionality. $\mathrm{Pb} 3$ is holodirectional with half occupancy in the asymmetric unit and has a regular eight coordinated geometry formed by both water and carboxylate oxygen atoms. Because of the high temperature and the basic condition of the reaction one of the amine hydrogens gets replaced by another aspartic acid moiety and forms the dimeric structure which is nothing but a secondary amine. Pbl and $\mathrm{Pb} 2$ are joined together by carboxylate oxygens to form hybrid double chains along the $a$ direction of the unit cell. These double chains are joined with one another through $\mathrm{Pb}-\mathrm{O}-\mathrm{Pb}$ linkage involving $\mathrm{Pb} 3$ and water oxygens to form hybrid layers parallel to the $a c$ plane of the unit cell. These hybrid layers are joined together by ligand moiety through amine nitrogen and carboxylic oxygen atoms along the $b$ direction of the unit cell to give the final threedimensional $\mathrm{I}^{2} \mathrm{O}^{1}$ hybrid structure (figure $2 \mathrm{~b}$ ). All the oxygen and the nitrogen atoms of the ligand are coordinated here. Polyhedral view of the structure shows rectangular pores formed by the threedimensional network (figure 2c). The structure clearly reveals the inversion centre symmetry as reflected on the P-1 space group of the crystal. Two types of $\mathrm{Pb}-\mathrm{O}$ bonds are present in the structure, the $\mathrm{Pb}-\mathrm{O}$ (water) bonds with a average bond length of $2.684 \AA$, the $\mathrm{Pb}-\mathrm{O}$ (carboxylate) bonds with bond lengths in the ranges 2.408(1)-2.672(1) $\AA$ (average $2.592 \AA$ ) along with $\mathrm{Pb}-\mathrm{N}$ bond length being $2.518 \AA$. The average $\mathrm{C}-\mathrm{O}, \mathrm{C}-\mathrm{N}$ and $\mathrm{C}-\mathrm{C}$ bond distances of the di-aspartate ligand are 1.263, 1.473 and $1.533 \AA$ respectively.

\section{Conclusions}

Reaction of $\mathrm{Ni}\left(\mathrm{L}-\mathrm{NHCH}(\mathrm{COO}) \mathrm{CH}_{2} \mathrm{COO}\right) \cdot 3 \mathrm{H}_{2} \mathrm{O}$ with the pyrazine linker under hydrothermal conditions gives a new compound of the formula $\mathrm{Ni}_{2}(\mathrm{D}$, L$\left.\mathrm{NHCH}(\mathrm{COO}) \mathrm{CH}_{2} \mathrm{COO}\right)_{2} \cdot \mathrm{C}_{4} \mathrm{H}_{4} \mathrm{~N}_{2}$, I, with extended three-dimensional connectivity. As the cobalt analogue of I has a similar structure, it may be surmised that similar compounds of other transition metals can also be prepared. The hydrothermal reaction of $\mathrm{Pb}\left(\mathrm{NO}_{3}\right)_{2}$ and L-aspartic acid yields an achiral threedimensional hybrid network with two-dimensional inorganic and one-dimensional organic connectivities. The compound has the composition $\mathrm{Pb}_{2.5}[\mathrm{~N}\{\mathrm{CH}$ $\left.(\mathrm{COO}) \mathrm{CH}_{2} \mathrm{COO}\right\}_{2} \cdot 2 \mathrm{H}_{2} \mathrm{O}$ ] wherein a secondary amine formed by the dimerisation of aspartic acid is the ligand.

CCDC-668748 and 668747 (I and III) contain the supplementary crystallographic data for this paper. These data can be obtained free of charge at www.ccdc.cam.ac.uk/conts/retreiving.html (or from Cambridge Crystallographic Data Centre, 12, Union Road, Cambridge CB21EZ, UK; fax: (+44) 1223336-033; e-mail: deposit@.ccdc.cam.ac.uk

\section{Acknowledgement}

The authors are grateful to Prof. C N R Rao for suggesting the problem and his constant support and guidance.

\section{References}

1. (a) Breck D W 1974 Zeolite molecular sieves (New York: Wiley); (b) Meier W M, Oslen D H and Baerlocher C 1996 Atlas of zeolite structure types (London: Elsevier)

2. (a) Cheetham A K, Férey G and Loiseau T 1999 Angew. Chem. Int. Ed. 38 3268; (b) Rao C N R, Natarajan S, Choudhury A, Neeraj S. and Ayi A A 2001 Acc. Chem. Res. 3480

3. Rao C N R, Behera J N and Dan M 2006 Chem. Soc. Rev. 35375 
4. (a) Rao C N R, Natarajan S, Vaidhyanathan R 2004 Angew. Chem. Int. Ed. 43 1466; (b) Ocwig N C, DFriedrichs O, O'Keefe M and Yaghi O M 2005 Acc. Chem. Res. 38 176; (c) Forster, P M and Cheetham A K 2003 Top Cat. 2479

5. Cheetham A K, Rao C N R and Feller R K 2006 Chem. Commun. 4780

6. Kitagawa S, Kitaura R and Noro S 2004 Angew. Chem. Int. Ed. $\mathbf{4 3} 2334$

7. Clearfield A 1998 Prog. Inorg. Chem. 47371

8. Clearfield A and Wang Z K 2002 J. Chem. Soc., Dalton Trans. 2937

9. Fujita M, Kwon Y J, Washizu S and Ogura K $1994 J$. Am. Chem. Soc. 1161151

10. Kepert C J, Prior T J and Rosseinsky M J $2000 \mathrm{~J}$. Am. Chem. Soc. 1225158

11. Chen B, Liang C, Yang J, Contreras D S, Clancy Y L, Lobkovsky E B, Yaghi O M and Dai S 2006 Angew. Chem. Int. Ed. $\mathbf{4 5} 1390$

12. Zhao X B, Xiao B, Fletcher A J, Thomas K M, Bradshaw D and Rosseinsky M J 2004 Science 3061012

13. Wong-Foy A G, Matzger A J and Yaghi O M $2006 \mathrm{~J}$. Am. Chem. Soc. 1283494

14. (a) Antolini L, Menabue L, Pellacani G C and Marcotrigiano G 1982 Dalton Trans. 2541; (b) Schmidbaur H, Bach I, RiedeMuller J, Helbig J and Hopf G 1988 Chem. Ber. 121 795; (c) Doyne T H, Pepinsky R and Watanabe T 1957 Acta Crystallogr. 10 438; (d) Kryger L and Rasmussen S E 1973 Acta Chem. Scan. 27 2674
15. (a) Zhang Y, Saha MK and Bernal I 2003 Cryst. Eng. Commun. 5 34; (b) Mizutani M, Maejima N, Jitsukawa K, Masuda $\mathrm{H}$ and Einaga $\mathrm{H} 1998$ Inorg. Chim. Acta 283 105; (c) Flook R J, Freeman H C and Scudder M L 1977 Acta Crystallog. B33 801; (d) Gramaccioli C M 1966 Acta Crystallogr. 21 600

16. (a) Dan M, Rao C N R 2005 Chem. Eur. J. 117102 ; (b) Dan M 2004 J. Mol. Struct. 706127 (and references therein)

17. Anokhina E V and Jacobson A J $2006 \mathrm{~J}$. Am. Chem. Soc. 1289957

18. Anokhina E V and Jacobson A J, Go Y B, Lee Y and Vogt T 2006 J. Am. Chem. Soc. 1289957

19. Vaidhyanathan R, Bradshaw D, Rebilly J N, Barrio J P, Gould J A, Berry N J and Rosseinsky M J 2006 Angew. Chem. Int. Ed. 45

20. Nakamoto K 1978 Infrared and Raman spectra of inorganic and coordination compounds (New York: Wiley Interscience)

21. (a) Sheldrick G M 1986 SHELXS-86 program for crystal structure determination (Gottingen, Germany: University of Gottingen); (b) Sheldrick G M 1990 Acta Crystallogr. A46 467

22. Sheldrick G M 1994 SADABS: Siemens area detector absorption correction program (Gottingen, Germany: University of Gottingen)

23. Sheldrick, G M 1993 SHELXS-93 program for crystal structure solution and refinement (Gottingen, Germany, University of Gottingen) 